\title{
Annotated Bibliography Of Selected Publications, Through 1996, Cheyenne Municipal Well-field Areas, Cheyenne, Wyoming
}

\author{
By Kathy Muller Ogle and Benjamin J. Jordan
}

\begin{abstract}
Annotated bibliographies for 55 hydrology and geology manuscripts pertaining to the Cheyenne municipal wells fields are listed in this report. For each manuscript, a citation is provided, a summary paragraph is presented, key words are listed, and a location of the report is given. The report lists manuscripts, conference proceedings, and guidebooks published by the U.S. Geological Survey, State of Wyoming, Geological Society of America, Wyoming State Geological Survey, private consultants, and University of Wyoming. Information on geological formations, structural geology, aquifer characteristics, water levels, well-field production, water-demand projections, and water quality is included in the manuscripts.

The Cheyenne Board of Public Utilities, the University of Wyoming, and the U.S. Geological Survey cooperatively produced this annotated bibliography to allow easy access and efficient utilization of existing data. The manuscripts were authored between 1910-96, reflecting work completed over a long period of development in the Cheyenne, Wyoming area. Some manuscripts did not receive broad distribution and indexing, thus were difficult to locate. By having the references and summaries within one report, time and effort to gather previous study results will be minimized.
\end{abstract}

\section{INTRODUCTION}

This report is an annotated bibliography of hydrology and geology manuscripts that pertain specifically to the Cheyenne municipal well fields. This report is a cooperative effort between the Cheyenne Board of Public Utilities, the University of Wyoming, and the U.S. Geological Survey (USGS). The earliest manuscript identified in this research was published in 1910 by N. H. Darton and others. Since that time, a total of 55 manuscripts have been produced that address various issues in the area of the Cheyenne municipal well fields. The report lists manuscripts, conference proceedings, and guidebooks published by the U.S. Geological Survey, State of Wyoming, Geological Society of America, Wyoming State Geological Survey, private consultants, and University of Wyoming.

Information on geologic formations, structural geology, aquifer characteristics, water levels, well-field production, water-demand projections, and water quality is included in the manuscripts. Some manuscripts did not receive broad distribution and indexing, thus were difficult to locate. Only one copy of some manuscripts could be located and those manuscripts often contained original data and analysis and, in some cases, original handcolored geologic maps.

For each manuscript, a citation is listed, the contents relating to the Cheyenne municipal wells fields are summarized, key words are noted, and a location of the manuscript is given. Information presented in this report will assist the managers of water supplies in the Cheyenne area and other users of hydrologic information by making previous work accessible. By having the references and summaries within one report, time and effort to gather previous study results will be minimized. Managers can use this report to determine what existing data are available and to take advantage of previous knowledge for new studies. 
Some terminology has changed over time. Two well fields supply water to the Cheyenne municipal system: the Cheyenne municipal well field and the Federal municipal well field. In some earlier reports, the Cheyenne municipal well field, or parts of it, have been called the Borie well field, the Bell well field, the Happy Jack well field, and the City well field. This report uses the term Cheyenne well field to cover inclusively all four designations. Transmissivity, a measure of the rate of water movement in an aquifer has replaced the older term transmissibility.

Stratigraphic names are those used in the publications and some names may not agree with stratigraphic nomenclature of North America. Rocks from Precambrian, Paleozoic, Mesozoic and Cenozoic eras are included in the publications. Most of the publications concentrate on descriptions of the Pennsylvanian, Permian, Cretaceous, Tertiary and Quaternary periods. Within the Tertiary period, sedimentary deposits from the Paleocene, Eocene, Miocene, and Pliocene are all discussed. Many reports contain detailed descriptions of the Casper Formation (of Permian age), White River (of Oligocene age), and the Ogallala Formation (of Miocene age). Limited information is also presented on the Pierre Shale, Fox Hills Sandstone, and Lance Formation (all of Upper Cretaceous age).

Some nomenclature changes or variations were noted. The Fox Hills Sandstone is called the Fox Hills Formation in one report. Likewise the Lance Formation was sometimes referred to as the Laramie Formation. Nomeclature associated with the White River Formation varied between authors. Some authors combined the deposits; others divided the deposits into the Chadron Formation and the Brule Formation. Variations were also used where the Chadron and Brule sedimentary deposits were considered members of the White River Formation or formations of the White River Group. In early reports, the Chadron Formation was called the Chadron sandstone and the Brule Formation the Brule clay. In some early reports, sedimentary deposits now described as the Ogallala Formation were included in the Arikaree Formation (of Miocene age). One author substituted the term Ogallala Group for Ogallala Formation and discussed sedimentary deposits named the Ash Hollow Formation within that group. Readers are cautioned that original reports should be consulted to determine geologic correlations.

\section{Purpose and Scope}

The purpose of this report is to provide a citation, brief annotated bibliography, list of key words, and location for manuscripts related to the geology and hydrology in the area of the Cheyenne municipal well fields. The scope of this report is limited to manuscripts that pertain directly to the Cheyenne municipal well fields and to manuscripts completed by 1996. Manuscripts not included are those of a general nature or those that cover the entire State of Wyoming or a larger area. The only exception was when a manuscript covering a larger area was known to include data and a discussion of the Cheyenne municipal well fields. Although an effort was made to include all relevant manuscripts, with additional time and effort other manuscripts might have been located.

\section{Description of Study Area}

The study area is limited to the two Cheyenne municipal well fields and surrounding area (figure 1).

\section{Acknowledgments}

The assistance and support of Jerry Mark, and Jim Van Dorn, of the Cheyenne Board of Public Utilities is gratefully acknowledged. Marvin Crist, retired U.S. Geological Survey hydrologist, generously shared his extensive experience and knowledge of the hydrology and geology of Laramie County. Dr. Peter Huntoon encouraged the collaboration between the University of Wyoming and the U.S. Geological Survey, which resulted in an expanded and more useful bibliography. 


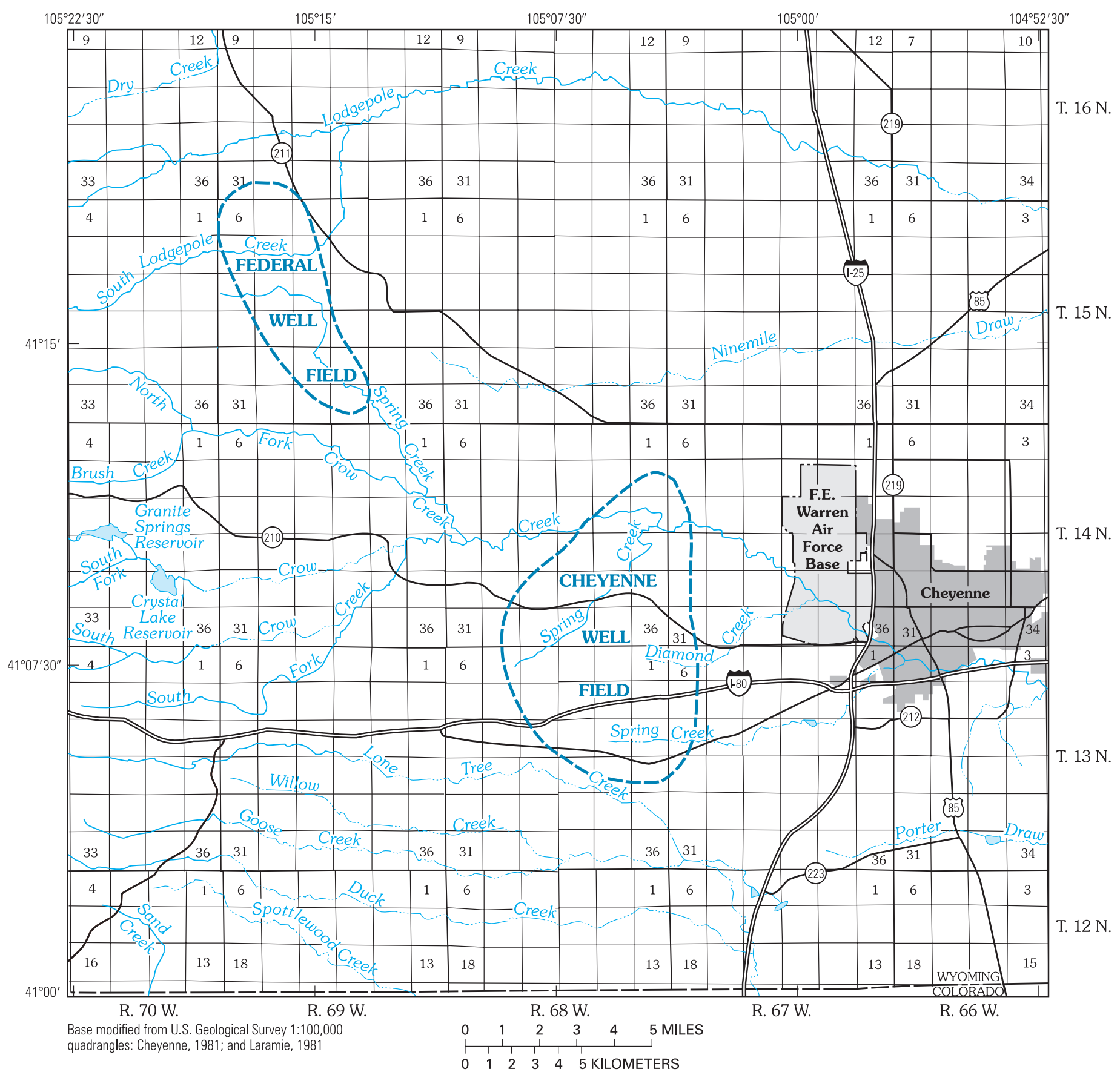

EXPLANATION

BOUNDARY OF CHEYENNE MUNICIPAL WELL FIELD

Figure 1. Location of Cheyenne, Wyoming, municipal well fields. 


\section{ANNOTATED BIBLOGRAPHY}

Anderman, G.G., and Ackerman, E.J., 1963, Structure of the Denver-Julesburg basin and surrounding areas: Rocky Mountain Association of Geologists, Guidebook No. 14, p. 170-175, 1 plate.

This article was published in a guidebook for the 1963 Rocky Mountain Association of Geologists field conference and describes the structural geology of the major uplifts bounding the Denver-Julesburg basin. Additionally, the authors determine ages of the uplifts according to depositional environments. The map accompanying the article depicts the top of the Mississippian Formations. It shows the Casper Formation at a depth of 6,400 feet below Cheyenne, and at a depth of 4,600 feet near the Cheyenne well field.

KEY WORDS: Denver-Julesburg basin, structural geology, Mississippian geology, Casper Formation LOCATION: University of Wyoming Geology Library

Avery, Charles, and Pettijohn, R.A., 1984, Generalized potentiometric-surface map of the High Plains Aquifer in Wyoming, 1981: U.S. Geological Survey Water-Resources Investigations Report 84-4033, 1 sheet.

This map report presents a 1981 potentiometric surface for the 8,190 square mile area of the High Plains aquifer in Wyoming. The authors include deposits of Oligocene age or younger, primarily the White River, the Arikaree, and the Ogallala Formations in the High Plains aquifer. The potentiometric surface was compiled from existing published potentiometric surfaces, water-level data, stream data, and records of the Wyoming State Engineer's Office. Potentiometric contours, at 100-foot intervals, are shown in the areas of the Cheyenne well fields.

KEY WORDS: Potentiometric surface, High Plains aquifer

LOCATION: U.S. Geological Survey

Babcock, H.M. and Bjorklund, L.J., 1956, Ground-water geology of parts of Laramie and Albany Counties, Wyoming, and Weld County, Colorado, U.S. Geological Survey, Water-Supply Paper 1367, 61 p., 1 plate.

In 1956, the USGS conducted an inventory of water resources in the Missouri River Basin. This report concentrated on the area surrounding Crow and Lone Tree Creeks. The authors described the geology and hydrogeology of the study area, and the water quality of ground water and surface water in the area.

The geology of the area was briefly described in the report. The boundary between the Fox Hills and Laramie Formations was established at the change from brackish deposits of coal and lignite (Laramie Formation) and marine deposits (Fox Hills Formation). Wells in the area were reported to yield moderate supplies of water. The Laramie Formation outcrops in the southern part of the study area and was described as providing moderate supplies of water 
from gravel beds. Composed of heterogeneous beds of silt, sand, and gravel, no water-supply data was available for the Chadron Formation. The Brule Formation was described from exposures in creek valleys. The authors noted fracturing in the Brule Formation in the valleys from which water has been used for irrigation. The Arikaree Formation was differentiated from the Ogallala by its lack of volcanic-source minerals and feldspars. The Arikaree was classified as being poor for water development. The Ogallala is described as a braided stream deposit, yielding large quantities of water to the west of Cheyenne. The authors stated that the Ogallala does not yield water to the east of Cheyenne because of insufficient saturated thickness. To the east of Cheyenne, alluvium and terrace deposits yield large amounts of water to domestic and irrigation wells. Lithologic logs of the wells used in the report are given in an appendix.

Water flow in the aquifers is described as generally east-southeast, following modern day stream valleys. Depth to the water table is depicted on an attached plate. The authors note that water levels declined throughout the study area but do not give drawdowns. The aquifer properties are given in the report.

Water quality for the wells and for Crow and Lone Tree Creeks is listed in the report. Streamwater sampling shows a decrease in the downstream direction of dissolved solids; sodium and potassium concentrations in stream water did not reflect that decrease.

KEY WORDS: Lone Tree Creek, Crow Creek, water supply, geology, ground water, water quality

LOCATION: University of Wyoming Library

Banner and Associates, 1957, Report on Cheyenne water supply, existing facilities and supplies: Cheyenne, Wyo., report submitted to the City of Cheyenne, Wyoming, $54 \mathrm{p}$.

The report compiled an inventory of existing facilities and production rates, as of 1957, for the Cheyenne municipal-water system. Population growth and water demand were projected to 1975 for predicting future needs. The study concluded that the facilities were adequate until 1961 or 1962. Additionally, it predicted that the Cheyenne well field could produce 4 to 5 million gallons per day. The report contains weekly consumption records from 1941 to 1956 and monthly well-production records from 1941 to 1956.

KEY WORDS: Water supply, water-production rates, Cheyenne population growth, wells, Cheyenne well field

LOCATION: Cheyenne Water and Sewer Department 
Bearlodge Ltd., Inc., 1990, 1992, Operation and maintenance manuals for Koppes No. 6, King No. 2, and Merritt No. 5 wells, Consultant's reports submitted to the City of Cheyenne, $30 \mathrm{p}$.

These three reports document pertinent information for the operation of three municipal wells. Included in these reports are well-construction data, pump data, electrical diagrams, piping diagrams, and well-design diagrams. Simple operating precautions also are presented.

KEY WORDS: Well field, well-construction data, well design, Cheyenne well field

LOCATION: Cheyenne Water and Sewer Department

Bearlodge Ltd., Inc., 1992, Most or all of the technical information that you would ever hope to have or know about the construction of the new Bell No. 8 well, Consultant's report submitted to the City of Cheyenne, 42 p.

This report is a compilation of data from the drilling and pump testing of the Bell No. 8 replacement well. Included in the report are the lithologic log, geophysical logs, aquifer-test data, and water-quality information. A Theis analysis of the aquifer-test data showed that the aquifer was leaky and had a transmissivity of 15,000 gallons per day per foot of drawdown. The water-quality data showed that the water meets all U.S. Environmental Protection Agency drinking-water standards.

KEY WORDS: Ground water, Cheyenne well field, geologic data, water quality, aquifer test

LOCATION: Cheyenne Water and Sewer Department

Black and Veatch, 1961, Review of the Banner and Associates report on the Cheyenne water supply plan: Cheyenne, Wyo., report submitted to the City of Cheyenne, Wyoming, 92 p.

This report was completed for the City of Cheyenne and reviews a report completed 4 years earlier by Banner and Associates. The needs and water uses of the Cheyenne municipal system are analyzed and recommendations are made for improvements. Black and Veatch projected higher demands for water, based on then-current consumption and population projections. Recommendations in the report include drilling new water wells and rehabilitating unspecified, existing wells.

KEY WORDS: Water supply, Cheyenne well field, water demand, population projections

LOCATION: Cheyenne Water and Sewer Department 
Black and Veatch, 1994, Cheyenne water supply master plan: Cheyenne, Wyo., report submitted to the City of Cheyenne and the Wyoming Water Development Commission, 181 p.

This report was completed for the City of Cheyenne and the Wyoming Water Development Commission. The entire Cheyenne municipal-water system was analyzed and recommendations for improvements, accounting for increases in future demand for water, were made. Ground-water modeling results for the Ogallala aquifer west of Cheyenne are presented. In addition, the Casper Formation was recommended as a target for exploration. The report reviewed the historical rates of withdrawal and recommended pumping the wells at the maximum adjudicated rate of 5,500 acre-feet per year.

KEY WORDS: Water supply, geology, ground water, Casper Formation, Ogallala aquifer, Cheyenne municipalwater system

LOCATION: Cheyenne Water and Sewer Department

Blackstone Jr., D.L., 1996, Structural geology of the Laramie Mountains, Southeastern Wyoming and Northeastern Colorado, Wyoming Geological Survey, Report of Investigations No. 51, 28 p., 3 plates.

Blackstone discusses the tectonic uplift of the Laramie Range and associated structural features, from Casper, Wyoming, to northern Colorado. Stratigraphy is briefly discussed for the basins surrounding the Laramie Range. East-west trending geologic cross-sections are drawn at several locations including the Borie well field, Mesa Mountain, and Horse Creek.

The cross-section through Borie extends from near Buford, Wyoming, east to Cheyenne. The cross-section depicts the Borie Anticline in a general form. There are three cross-sections through Mesa Mountain which show two thrust faults. The Casper Formation is not connected across the faults, and formations are nearly vertical to overturned. Sediments of Tertiary age cover all but a small part of the Cretaceous Formations, which dip slightly to the east of the lower thrust fault. The cross-section in the area of Horse Creek shows a thrust fault along the mountain front and the Horse Creek Anticline to the east of the station.

Blackstone notes the absence of rocks of Paleocene age east of the Laramie Range and attributes this to sediments washing north into the Powder River Basin during the Paleocene. He also states that the Fox Hills Sandstone was deposited during the last marine regression in the Cheyenne area.

KEY WORDS: Laramie Range, tectonics, depositional geology, structural geology

LOCATION: University of Wyoming Library 
Blackstone, Jr., D.L., 1975, Late Cretaceous and Cenozoic history of Laramie Basin region, southeast Wyoming, in Curtis, B.F., ed., Cenozoic history of the southern Rocky Mountains: Geological Society of America, Memoir 144, p. 249-279.

Blackstone outlines the depositional environments and the different sequences of deposits that occurred from the Late Cretaceous to the Cenozoic. Although the report focuses on the Laramie basin, it makes limited reference to the geology near Cheyenne, Wyoming. Maps of depositional environments include the Cheyenne area. Blackstone notes that rocks of Paleocene age are rare on the eastern edge of the Laramie Range. In addition, Blackstone attributes deposits of arkoses and conglomerates west of Cheyenne to a change in climate, not tectonic activity. Speciman Mountain, a volcano in Colorado, is cited as the source of rhyolitic clasts found in the Ogallala Formation in Laram*ie County.

KEY WORDS: Laramie Range, geology, climate change

LOCATION: University of Wyoming Geology Library

Bjorklund, L.J., 1959, Geology and ground-water resources of the upper Lodgepole Creek drainage basin, Wyoming, U.S. Geological Survey, Water Supply Paper 1483, 31 p., 2 plates.

This report was completed as part of the Missouri River Basin water resources project of the 1950's. The study area encompassed the stream valley of Lodgepole Creek, from its headwaters to the Wyoming-Nebraska state line. The report gave geologic descriptions of possible water bearing formations in the stream valley and listed water-quality data for ground and surface water in the area.

The author mentioned rocks of pre-Tertiary age only in passing. He noted their attitude at the Laramide thrust fault, and the 5 degree dip they have east of the fault. No wells were completed in the Chadron Formation in Lodgepole valley. Water yields were predicted to be low because of the fine-grained sediments. The Brule Formation was described as a fractured siltstone in valley bottoms. Water yield was low except where the fractures occur. Wells in the Brule yield 360-2,000 gallons per minute (gpm). The Arikaree Formation is a finegrained sandstone with minor amounts of water. The Arikaree was deposited on the eroded surface of the Brule. The lateral extent of the Arikaree was unknown for two reasons. First, the Arikaree was probably deposited only in the low-lying parts of the Brule. Second, the Arikaree would have been eroded before the Ogallala Formation was deposited. The Ogallala Formation was described as a braided-stream deposit, with lenses of gravel, sand, and silt. The formation thins to the east of the study area. It yields 200-530 gpm to wells. Deposits of Quaternary age are located in the stream valleys, and where the alluvium is saturated, were expected to produce large amounts of water to wells. Wells completed in the alluvium yielded 425-1,500 gpm.

The potentiometric surface was mapped on an appended plate. Depths to ground water range from 10-300 feet. Stream flow and ground-water flow are eastward. The aquifers are recharged primarily by infiltration of precipitation. 
Water-quality data for the wells were relatively uniform regardless of the source rocks. The water type was calcium bicarbonate with an average dissolved-solids measurement of 277 parts per million. Surface-water samples collected from Lodgepole Creek showed the same characteristics as the ground water, and had approximately the same values. The hardness and dissolved solids increased downstream. The water was suitable for all but strict industrial uses.

KEY WORDS: Lodgepole Creek, water supply, geology, ground water, water quality

LOCATION: University of Wyoming Library

Brady, R.T., 1949, Geology of the east flank of the Laramie Range in the vicinity of Federal and Hecla, Laramie County,

Wyoming: Laramie, Wyo., Master's thesis, Department of Geology, University of Wyoming, 41 p., 9 pls.

The subject of this thesis is the surface geology of Townships 14 and 15 North, Ranges 69 and 70 West. The report describes the general lithology and structure of the study area. The author divided the Ogallala Formation into three members, basing that division on type sections located in Nebraska.

KEY WORDS: Geology, Horse Creek, Laramie Range, Casper Formation, Ogallala Formation, Tertiary deposits

LOCATION: University of Wyoming Geology Library

Cady, R.C., 1936, Report on the test well at the Veterans' Administration Facility, Cheyenne, Wyoming: Cheyenne, Wyo., report prepared in cooperation with the Veterans Administration, p. 39.

Cady limits his discussion to two groups of rocks underlying Cheyenne: (1) older rocks of Cretaceous age, that were structurally affected by the Laramide or mountain building event and (2) younger rocks and those of Tertiary age that lie at or near the surface, with sediments that are derived from the older rocks. Cady gives lithographic descriptions of the Arikaree Formation, the Brule clay, the Chadron sandstone, and the Fox Hills Sandstone.

A lithologic log of the test well drilled at the Veterans' Administration Facility is included in the report. Water-yielding characteristics are assessed for the Chadron sandstone, Fox Hills Sandstone, Pierre Shale, and Niobrara Limestone. A qualitative description is given of the quality of the water from a sandstone lens within the Pierre Shale from 956-1,038 feet. He estimates the thickness of the Brule clay to be about 290 feet, the Chadron sandstone to be about 233 feet and the Fox Hills Sandstone to be about 226 feet in the test well at the Veterans Administration Facility. 
It appears that what is identified in Cadys' report as the Arikaree Formation is now considered to be the Ogallala Formation of Tertiary age. There is some discussion of the water-yielding characteristics of those sediments. One City of Cheyenne well was reported to flow $175 \mathrm{gpm}$ and was pumped at $450 \mathrm{gpm}$. Also included are logs or hydrologic information on 63 wells in the area.

KEY WORDS: Ground water, well logs, water quality, Veterans Administration well, Arikaree Formation, Brule, Chadron, Fox Hills Sandstone, Pierre Shale, Ogallala Formation

LOCATION: U.S. Geological Survey. Only one copy of this report was located.

Centrac Associates Inc., 1985, Report of investigations to the Board of Public Utilities, Water well testing and evaluations: Cheyenne, Wyo., report submitted to the City of Cheyenne, Wyoming, 146 p., 2 pls.

Centrac Associates Inc. completed evaluations of the Cheyenne wells, then selected 10 wells for aquifer testing. The aquifer tests were used to determine transmissivities and storage coefficients for each of the well fields. Maximum pumping rates for three of the well fields were calculated. Appended to the report are historical pumping data from the Cheyenne well system.

KEY WORDS: Geology, water supply, aquifer tests, transmissivities, storage coefficients, well data, pumping data

LOCATION: Cheyenne Water and Sewer Department

City of Cheyenne, Water and Sewer Department, no date, Well drilling logs, City records.

These three binders are collections of original data from Cheyenne municipal wells. Data includes locations, elevations, lithologic logs, casing schedules, aquifer-test summaries, water production records, and driller's names.

KEY WORDS: Well completion information, lithologic logs, water production

LOCATION: Cheyenne Water and Sewer Department 
Crist, M.A., 1970, Summary of the water-level and pumpage data in the Cheyenne and Federal municipal well fields for the period April 1969 to April 1970, Cheyenne, Wyoming: Cheyenne, Wyo., Administrative Report prepared by the U.S. Geological Survey for the Board of Public Utilities, 29 p.

Water-level and pumpage data from April 1969 to April 1970 is summarized for the Cheyenne and Federal municipal well fields, with major emphasis on the Cheyenne municipal well field. Maps showing the following data for the Cheyenne well field are included: well locations, net change in water levels from April 1969 to April 1970, and the net decline of water levels from 1942-70. Also included are selected hydrographs from monitor wells located in both the Cheyenne and Federal well fields.

The Cheyenne well field is divided into three areas based on hydrologic interference: Groups I, II, and III. Key observation wells were identified for each group. Pumpage withdrawals were calculated for each group. A map of water-level changes between April 1969 and April 1970 documents a decline in water levels of up to 30 feet in the northern part of the Cheyenne field and a rise in water levels of up to 30 feet in the southern part. Between $1942-70$ a decline of up to 60 feet was recorded in the western part of the field.

The Federal well field had a net decline of 1.5 feet in average water levels between April 1969 to April 1970.

KEY WORDS: Water levels, pumpage, Cheyenne well field, Federal well field, observation wells, water-level changes

LOCATION: U.S. Geological Survey

Crist, M.A., 1980, Effect of pumpage on ground-water levels as modeled in Laramie County, Wyoming: U.S. Geological Survey Water-Resources Investigations Open-File Report 80-1104, 26 p., 5 pl.

This report concentrates primarily on irrigation pumpage effects on ground-water levels in Laramie County, however the effect of pumpage of the City of Cheyenne municipal well fields is included. Water-level trends, lineaments, hydrographs, inputs and output from the ground-water model, calculated changes in water levels between 1920-87 are presented. Water-budget estimates for the area ground-water modeled are presented.

KEY WORDS: Ground-water model, irrigation pumpage, water levels, water-level trends, lineaments, water budget

LOCATION: U.S. Geological Survey 
Crist, M.A., 1985, Altitude and configuration of the water table, and depth to water near Cheyenne, Wyoming, May 1984: Cheyenne, Wyo., Water-Resources Investigations Report 85-4154, 1 sheet.

This map report shows the water table on a part of F.E. Warren Air Force Base. Wells, springs, test holes and stream-discharge sites used to construct the water-level map are shown. The approximate area of a landfill located on the Base is included.

KEY WORDS: F.E. Warren Air Force Base, water levels, water-table map, landfill

LOCATION: U.S. Geological Survey

Crist, M.A., and Borchert, W.B., 1972, The ground-water system in southeastern Laramie County, Wyoming: U.S. Geological Survey Open-File Report 72-80, 53 p.

The authors examine the effects of the approximately 230 irrigation wells that were being pumped in southeastern Laramie County in 1971. The report does not directly address the areas around the Cheyenne and Federal well fields, but some of the data and analysis may be applicable to the well-field areas. A total of 29 test holes were drilled as part of this study. Emphasis of the report is on the aquifers in the White River Formation and the terrace deposits. A description of the secondary permeability in the White River Formation, observed at a depth of 239 feet, is included. Methods used to increase permeability locally-connecting wells in close proximity and chain saw cuts -- are explained. Transmissivity and storage coefficients are presented for an aquifer test conducted October 28, 1970, of well 14-60-5bcb2 completed in the White River Formation.

KEY WORDS: White River Formation, pumpage, water-table maps, water levels, transmissivity, storage coefficients, terrace deposits, test holes, secondary permeability

LOCATION: U.S. Geological Survey

Cooley, M.E. and Crist, M.A., 1994, Geohydrology of the High Plains Aquifer System, Cheyenne Urban Area, Wyoming, U.S. Geological Survey Water-Resources Investigations Report 92-4047, 4 plates.

This report encompasses the urban Cheyenne, Wyoming area. Cooley and Crist give brief summaries of geologic deposits within the Ogallala and White River Formations. The aquifer systems, water-level conditions, perched-water zones, recharge, discharge, and ground-water movement are discussed. Specific conductance of water collected in wells, streams, and lakes in Cheyenne, and the effects of urban development are discussed. Maps showing the effects of urban development, the potentiometric surface in the upper part of the High Plains aquifer system, and geologic deposits and features are included.

KEY WORDS: Geology, ground water, water quality, potentiometric surface, Ogallala Formation, White River Formation, lakes and streams

LOCATION: U.S. Geological Survey 
Darton, N.H., Blackwelder, Eliot, and Siebenthal, C.E., 1910, Geologic atlas of the United States--Laramie-Sherman Folio 173: Washington, D.C., U.S. Geological Survey, 34 p., 8 pl.

This 1910 Folio presents descriptions of the geography, geology, and economic geology for the areas of the Laramie and Sherman quadrangles ( $41^{\circ}$ to $41^{\circ} 30^{\prime}$ North latitude, $105^{\circ}$ to $106^{\circ}$ West longitude), an area that includes the Cheyenne well fields. The descriptions of the geologic units are detailed and often include locations so that the site can be revisited.

Topographic maps, geologic cross-sections, and geologic maps are included with the text. Geologic type sections are provided and selected fossils are listed.

Ground-water resources are discussed in the economic geology section entitled "Underground Waters". The authors focus on the ground-water resources of the Laramie Quadrangle. The report mentions that the older sediments in the Sherman quadrangle dip so steeply that the potential for obtaining ground-water supplies was deemed limited. The authors noted that ground-water supplies were primarily obtained from deposits of Tertiary age, although some of the deeper sandstones may yield water or flowing wells.

KEY WORDS: Geologic descriptions, structural geology, geologic maps, ground water

LOCATION: U.S. Geological Survey

Diffendal, R.F., Jr., 1984, Comments on the geologic history of the Ogallala Formation in the southern panhandle of Nebraska, in George Whetstone, ed., Ogallala Aquifer Symposium II, Lubbock, Tex., 1984, Proceedings: Texas Tech University Water Resources Center, p. 194-216.

This paper discusses depositional issues and controversies associated with the Ogallala Formation. Although the study area described is located in western Nebraska, it is close enough to Wyoming to have applicability. Diffendal describes the depositional filling of stream channels during the development of the Ogallala Formation. He discusses the conflicting theories on the Ogallala Formation: alluvial fans, lacustrine, or piedmont alluvialplain deposition. He also describes paleovalley fills, tributary fills and volcanic-ash deposits.

KEY WORDS: Ogallala Formation, depositional models, ash beds

LOCATION: U.S. Geological Survey 
Dutton, A.R., 1994, Sources and ages of ground water in unconfined and confined aquifers beneath the U.S. High Plains: Austin, Tex., Bureau of Economic Geology, The University of Texas at Austin, 43 p.

This technical report was completed under a research award for the U.S. Geological Survey. A total of 32 ground-water samples were collected from the unconfined High Plains aquifer and confined aquifers in various hydrostratigraphic units beneath the High Plains aquifer. The wells were in an area extending north from New Mexico and Texas into Wyoming and Nebraska. Measurements of $\zeta \mathrm{D}$ (delta deuterium), $\zeta^{18} \mathrm{O}, \zeta \zeta^{13} \mathrm{C},{ }^{14} \mathrm{C},{ }^{3} \mathrm{H}$, and ${ }^{36} \mathrm{Cl} / \mathrm{Cl}$ and ionic constituents were made on the water samples collected from the wells. Four of the wells sampled are located in Laramie County, Wyoming; one is located in the City of Cheyenne Bell well field (Cheyenne well field). The well number, local name, and the formation from which water was sampled are listed in table 1.

Table 1. Wells in Laramie County, Wyoming with sample results in the Dutton (1994) report and from letter to the Wyoming District

\begin{tabular}{clc}
\hline Dutton report well no. & \multicolumn{1}{c}{ Local name } & Formation \\
\hline PAL 9 & City of Cheyenne, Bell No. 12 & Ogallala \\
PAL 10 & Lodgepole Potato Inc. & Lance \\
PAL 11 & City of Pine Bluffs, No. 3 & Ogallala \\
PAL 12 & Coastal Chemical Inc. & Lance \\
\hline
\end{tabular}

Dutton concludes that all $\zeta \mathrm{D}$ and $\zeta^{18} \mathrm{O}$ from the confined and unconfined ground water plot along the meteoric water line and are consistent with the modern distribution of meteoric water across North America. He reports that, although the age dates are uncertain, calculations indicate that ground water from the unconfined aquifer probably ranges from 25 years to less than 1,000 years old, while ground water in the confined aquifers range from between 20,000 and 32,000 years old. Lateral flow and leakage as recharge mechanisms are discussed, as well as climatic influences.

KEY WORDS: High Plains aquifer, Lance Formation, Ogallala Formation, ground water, isotopes, leakage, recharge, age dating, chemical quality

LOCATION: $\quad$ U.S. Geological Survey. Only one copy of this report was found. 
Foley, F. C., 1942, Progress Report on geology and ground-water resources of the Cheyenne Area, Wyoming: Cheyenne, Wyo., report prepared with the cooperation of the Wyoming State Planning and Conservation Board and the City of Cheyenne, 95 p., 4 pl.

Foley conducted an intensive study of the Cheyenne municipal wells including continuous water-level monitoring and aquifer tests. By June 1942, the population of the Cheyenne area, including Fort Frances E. Warren (now F.E. Warren Air Force Base), was estimated to be about 40,000. The City, Union Pacific Railroad, Colorado and Southern Railroad, Fort Frances E. Warren, and the U.S. Agricultural Research Field Station were identified as major water users, with Union Pacific Railroad being the largest user during the winter of 1941-42. A history of the development of ground-water supplies is presented, starting in 1933-34 with the installation of a collection gallery at Ware, followed by the installation of wells at Silver Crown in 1935-36, and finally followed by the installation of wells in the Cheyenne well field in 1935-42. The amount of water supplied by wells varied from 16 to 38 percent. The following formations are described: Casper, Fox Hills Sandstone, Chadron, Brule, Ogallala, and alluvial deposits. A geologic map also is included.

Water levels, aquifer tests, well data, and flow data are described. Field visits were made to 90 wells to collect data; weekly water-levels were measured in 25 wells for about one year. A water-table map is included in the report. Recovery data from a 2 -week period were used to calculate specific capacity and transmissivity. Well logs, pumping records, interference data, water-level recovery data, and well yields are included. Foley calculated the Ogallala Formation will transmit about 820,000 gallons per day for each mile of aquifer width, and he notes that this value is comparable to the 667,000 gallons per day for each mile of aquifer he calculated based on discharge to Crow Creek.

Recharge and discharge are discussed. Monthly summaries of precipitation in Cheyenne for normal, 1940, 1941, and 1942 (partial) are presented. Tables summarizing discharge of Lone Tree Creek near Granite Canyon for 1933-38 and the discharge of springs for 1941-42 are included. He describes the spring line from the edge of the Brule Formation outcrop near Warrenton, north and west of Cheyenne.

KEY WORDS: Ground water, transmissivity, storage coefficient, water levels, spring line

LOCATION: U.S. Geological Survey. Only one copy of this report was located. 
Inberg-Miller Engineers, 1994, Report of well sampling, City of Cheyenne landfill, second quarter 1994, report submitted to the City of Cheyenne, $58 \mathrm{p}$.

This report presents the results of ground water sampled from numerous monitoring wells at the landfill site west of Cheyenne and at the nearby Cheyenne municipal wells. The testing period began in July 1991 and continued into 1994. Chemical constituents and physical characteristics sampled include: calcium, magnesium, sodium, potassium, bicarbonate, sulfate, chloride, total-dissolved solids, and $\mathrm{pH}$. Wells were sampled from unconfined aquifers, confined aquifers, and perched aquifers. Water-sampling data and plots of the data are given in the report.

KEY WORDS: Landfill, monitoring, ground water, water quality

LOCATION: Cheyenne Water and Sewer Department

Kennedy, H.I., and Green, S.L., 1994, Ground-water levels in Wyoming, 1984 through September 1993: U.S. Geological Survey Open-File Report 94-466, 123 p.

This report includes hydrographs for 26 monitor wells in Laramie County, including some wells in the area of the Cheyenne municipal well fields. A map showing general well locations is included. A table is included listing the well location, well depth, use of water, principal geologic source of the water, the years for which water-level records are available, and dates of highest and lowest water levels.

KEY WORDS: Ground-water levels, hydrographs, well information

LOCATION: U.S. Geological Survey 
Knight, S.H., and Morgan, A.M., 1937, Report on the underground water resources of Crow Creek Valley, Laramie County, Wyoming: Laramie, Wyo., The Geological Survey of Wyoming, University of Wyoming, 16 p., 1 pl.

This report includes the part of Crow Creek drainage basin that lies within Laramie County, Wyoming. Stream reaches of the North, Middle and South Forks of Crow Creek, Crow Creek, and Porter Draw are described as either perennial or intermittent. Geologic descriptions include outcrops of the Fox Hills Formation and the Chadron Formation. At the time of this report, the surficial geology in the Cheyenne area was called the Arikaree Formation, the sediments are now called the Ogallala Formation. The authors observe that good stock or domestic wells could be obtained at depths of less than 200 feet in the area. Artesian wells, completed in sand and gravel beds at depths ranging from 50 to 200 feet, were in the western part of the study area. Flowing wells also were reported in downstream sections of valleys along Crow Creek and Clear Creek, and on the bottom of a wide, low swale 2 miles south of Cheyenne in the Allison Addition. The permeability variations of the Arikaree Formation are discussed, as well as the increased secondary permeability of the Brule Formation due to fractures and joints. A table of wells listing well name, location, depth of well, depth to water, and specific capacity is included. A hand-colored geologic map is included.

KEY WORDS: Surface water and ground water interaction, Fox Hills Formation, Chadron Formation, Ogallala Formation, water levels, artesian wells, permeability, secondary permeability.

LOCATION: U.S. Geological Survey. Only one copy of the report was located.

\section{Larson, L.R., 1984, Ground-water quality in Wyoming: U.S. Geological Survey Water-Resources Investigations} Report 84-4034, 71 p.

This report identifies Laramie County as one of the two counties in Wyoming having the best water-quality, based on median dissolved-solids concentrations. The data primarily reflect natural conditions, not anthropogenic contamination problems. A median dissolved-solids concentration of $217 \mathrm{mg} / \mathrm{L}$ for 17 samples collected from the Ogallala Formation and of $257 \mathrm{mg} / \mathrm{L}$ for 11 samples collected from the White River Formation in Laramie County is reported. Dissolved-solids concentrations of $625 \mathrm{mg} / \mathrm{L}$ for a well 713 feet deep and $252 \mathrm{mg} /$ L for a well 1,070 feet deep in the Lance Formation are listed.

KEY WORDS: Ground-water quality, median dissolved-solids concentration, Ogallala Formation, White River Formation, Lance Formation

LOCATION: U.S. Geological Survey 
Loeffler, R.J., 1939, The stratigraphy of a portion of the east side of the Laramie Range, Laramie County, Wyoming: Laramie, Wyo., M.A. Thesis, Department of Geology, University of Wyoming, 45 p.

This thesis focused on sections of Paleozoic and Mesozoic age deposits along Horse Creek, Lodgepole Creek, and Crow Creek in western Laramie County. The author describes the lithology in detail and correlates the formations from three measured sections. The author notes that the Fox Hills Sandstone may be an excellent water-bearing unit.

KEY WORDS: Laramie Range, geology, Cretaceous geology, Crow Creek, Lodgepole Creek, Horse Creek, Fox Hills Sandstone

LOCATION: University of Wyoming Geology Library

Lowry, M.E., and Crist, M.A., 1967, Geology and ground-water resources of Laramie County, Wyoming, with a section on Chemical quality of ground water and of surface water, by John R. Tilstra: U.S. Geological Survey WaterSupply Paper 1834, 69 p., 2 pls.

The study area for this water-supply paper is Laramie County. The report concentrates primarily on aquifers of Tertiary age. Limited information is presented on pre-Tertiary aquifers. The White River, Arikaree, and Ogallala Formations and the alluvium are identified as principal aquifers. The possibility that piping in the White River Formation enhances secondary permeability is discussed. Transmissivity, storage coefficient, specific capacity, and length of test are tabulated for aquifer tests in the Ogallala Formation and in the alluvium. Ground-water and surface-water interaction in the area of the Cheyenne well field is discussed, and changes in water levels in and near the well field are presented. Ground-water recharge and discharge are discussed as well as water quality. Water-quality data and well data are tabulated. A hydrologic map and a geologic map of Laramie County are included.

KEY WORDS: Ogallala Formation, Arikaree Formation, White River Formation, ground water, transmissivity, storage coefficient, specific capacity, aquifer-test results, water quality, water levels

LOCATION: U.S. Geological Survey 
Luckey, R.R., Gutentag, E.D. and Weeks, J.B., 1981, Water-level and saturated-thickness changes, predevelopment to 1980 in the High Plains Aquifer in parts of Colorado, Kansas, Nebraska, New Mexico, Oklahoma, South Dakota, Texas and Wyoming: U.S. Geological Survey, Hydrologic Investigations Atlas, 2 sheets.

This report presents water-level changes in the High Plains aquifer from predevelopment to 1980 in an area that extends from Texas to South Dakota and includes the southeastern part of Wyoming. The author states, with regard to the Cheyenne, Wyoming area: "Water-level declines greater than 25 feet in Laramie County, Wyoming, result directly from the stress imposed upon the aquifer by pumpage from the Cheyenne municipal well field." A decrease in saturated thickness in the area of Cheyenne's Federal well field is shown to range from 10 to 25 percent.

KEY WORDS: High Plains aquifer, water levels, water-level declines, saturated thickness

LOCATION: U.S. Geological Survey

Mason, J.P., and Green, S.L., 1996, Ground-water levels in Wyoming, January 1986 through September 1995: U.S. Geological Survey Open-File Report 96-648, 119 p.

This report includes hydrographs of 27 monitor wells in Laramie County, including some wells in the area of the Cheyenne municipal well fields. A map showing general well locations is included. A table is included listing the well locations, well depth, use of water, principal geologic source of the water, the years for which water-level records are available, and dates of highest and lowest water levels.

KEY WORDS: Ground-water levels, hydrographs, well information

LOCATION: U.S. Geological Survey

McGookey, D.P., 1952, Pennsylvanian and early Permian stratigraphy of the southeast portion of the east flank of the Laramie Range, Wyoming and Colorado: Laramie, Wyo., M.A. Thesis, Department of Geology, University of Wyoming, 45 p., 2 pls.

The author studied formations of Pennsylvanian and lower Permian age in southern Laramie County, Wyoming, and northern Larimer County, Colorado. He describes the lithology of the formations in detail and notes that the Fountain Formation is not present north of Granite Canyon, and that the Casper Formation thins towards the south in the study area.

KEY WORDS: Geology, Pennsylvanian, Permian, Casper Formation, Fountain Formation

LOCATION: University of Wyoming Geology Library 
McGrath, Timothy, and Dugan, J.T., 1993, Water-level changes in the High Plains Aquifer--predevelopment to 1991:

U.S. Geological Survey Water-Resources Investigations Report 93-4088, 53 p.

This regional report includes generalized information about the High Plains aquifer in the Cheyenne area. Maps in the report show selected observation-well locations, average annual precipitation and departures, potential evapotranspiration, average annual potential groundwater recharge, ground-water withdrawal rates, average annual consumptive irrigation requirement for corn, average annual net ground-water withdrawal rate of irrigated corn, water-level changes, saturated thickness, and well locations for water-level measurements.

KEY WORDS: High Plains aquifer, water-level changes

LOCATION: U.S. Geological Survey

McGrew, P.O., 1953, Tertiary deposits of southeastern Wyoming, in Eighth Annual Field Conference--Laramie Basin, Wyoming and North Park, Colorado, 1953: Laramie, Wyo., Wyoming Geological Association and University of Wyoming, p. 61-64.

A short discussion of the ages and correlation issues associated with Paleocene, Eocene, Oligocene, Miocene, and Late Miocene-Early Pliocene rocks is presented. The distinction between the Chadron Formation and the Brule Formation of the White River Group is discussed in relation to the Cheyenne area. He also mentions that the Ogallala Group in the Cheyenne area represents the lower part of the Ash Hollow Formation. Briefly mentioned are mammal fossils, arkosic and volcanic pebbles, and the correlation uncertainties within the Ogallala Group.

KEY WORDS: Tertiary deposits, Paleocene, Eocene, Oligocene, Miocene, Late Miocene-Early Pliocene, sediments, correlation, Chadron Formation, Brule Formation, Ogallala Formation

LOCATION: Wyoming State Library

McMinn, P.M., 1963, Borie Field, in Geology of the northern Denver Basin and adjacent uplifts: Rocky Mountain Association of Geologists, Guidebook No. XX, p. 234-235.

This report describes the Borie Oil Well Field. The report analyzes the Borie anticline and concludes that the anticline may be cored by a high-angle reverse fault. It describes oil production in the area.

KEY WORDS: Borie Oil Well Field, anticline, oil, Cretaceous geology

LOCATION: University of Wyoming Geology Library 
Meinzer, O.E., 1917, Groundwater for irrigation in Lodgepole valley, Wyoming and Nebraska, U.S. Geological Survey, Water-Supply Paper 425-B, 69 p.

This report was prepared in response to farmers inquiries about irrigation wells within Lodgepole valley. The author describes the geology of the area and the topographic features within the valley. The flow in various portions of the stream is discussed in detail. Flow in the stream was measured at 60 stations within Wyoming, Nebraska, and Colorado. The author notes reaches where the stream gains and loses flow.

The geologic descriptions are based on Darton's work of 1910. The fractured permeability of the Brule Formation is mentioned as an attractive target for water production. Alluvial gravels are listed as the most consistent water-producing units.

Water-quality samples were collected at several of the flow measuring stations. The results of the analysis are displayed in two tables. Dissolved-solids measurements ranged from 212 to 501 parts per million.

The lack of success of wells in the Lodgepole valley for irrigation is attributed to economics. The well pumps were driven by internal-combustion engines, which were inefficient and often unreliable. The author predicts that many wells would be productive if electricity could be used as the energy source.

KEY WORDS: Lodgepole Creek, surface water, geology, ground water, wells

LOCATION: University of Wyoming Library

Minick, J.N., 1951, Tertiary stratigraphy of southeastern Wyoming and northeastern Colorado: Laramie, Wyo., M.A. Thesis, Department of Geology, University of Wyoming, 53 p., 1 pl.

Minick studied the surface exposures of formations of Tertiary age along the Wyoming and Colorado border from Pine Bluffs to Granite Canyon, Wyoming. The author provides a general description of the lithology of the formations. The divisions of the formations are based on extensive fossil evidence.

KEY WORDS: Geology, stratigraphy, Miocene, Pliocene, Oligocene, paleontology, Tertiary

LOCATION: University of Wyoming Geology Library 
Moore, F.E., 1959, The geomorphic evolution of the east flank of the Laramie Range, Colorado and Wyoming: Laramie, Wyo., Ph.D. dissertation, Department of Geology, University of Wyoming, 123 p., 6 pls.

Moore investigated the geomorphology of the region west of Cheyenne to the Laramie Range. The author describes the lithology of the rocks from the Precambrian to the Tertiary in the study area. The lithology of the formations was used to determine the depositional environments of the sediments. Moore states that the Arikaree Formation is not well developed or is nonexistent in the region studied. The lateral discontinuity of the Ogallala Formation made characterization of the formation difficult. The author found evidence of channel deposits, with potentially high transmissivity, in the Ogallala Formation.

KEY WORDS: Geology, Laramie Range, Ogallala Formation

LOCATION: University of Wyoming Geology Library

Morgan, A.M., 1946, Progress report on the geology and ground-water resources of the Cheyenne area, Wyoming: U.S. Geological Survey Open-File Report, 55 p., 6 pl.

This report was completed during World War II when Cheyenne was estimated to have a population of about 35,000 with an additional 20,000 to 30,000 persons stationed at Fort Francis E. Warren. The report concentrates on aquifers of Tertiary age and the Cheyenne well field. Infiltration of streams and precipitation are identified as the principal recharge source for the Ogallala Formation. Total recharge was estimated to be about 10 million gallons per day (MGPD) with about 2.5 MGPD recharge from Lone Tree, Duck and Goose Creeks, and about 7.7 MGPD from infiltration of precipitation. A precipitation recharge rate of 0.83 inches was calculated. Discussion of permeable zones with high-yield potential in the Brule Formation and Ogallala Formation is included. The spring line west of Cheyenne is used as an approximate boundary of appreciable thickness of water-bearing beds. Three groups of wells in the Cheyenne well field are identified. The alignments of various sand and gravel beds indicate that the Cheyenne well field might be developed in an alluvial fan built up by Lone Tree Creek. Water-level fluctuations from natural effects and well-field pumpage are discussed. A total of 31 wells had been drilled in the Cheyenne well field area: 20 wells were successful and 11 wells were considered failures. Specific capacity, transmissivities, and rate of pumpage for 1941-45 are reported for the wells. The collection gallery in Crow Creek Valley at Ware and shallow wells at Silver Crown and their effect on flow in Crow Creek are described. The alluvial aquifer was identified as having the potential for additional development. A water-quality table consisting of major ions for selected wells in the Ogallala Formation and Brule Member is included. The appendix includes logs of Cheyenne municipal wells plus 5 additional wells. Plates showing hydrographs, graphs of pumpage and precipitation, and water-surface contours are included (1 plate is missing).

KEY WORDS: Recharge, water levels, Cheyenne well field, streamflow, logs, Ogallala Formation, Brule Member, alluvial aquifer, transmissivity, specific capacity

LOCATION: U.S. Geological Survey -- Only one copy of this report was located. 
Ringen, B. H., 1973, Summary of water-level and pumpage data in Cheyenne and Federal municipal well fields, April 1, 1972 to April 2, 1973: U.S. Geological Survey Open-File Report October 1973, 27 p.

Data and analyses in this report are separated into the Cheyenne well field and the Federal well field.

In the Cheyenne well field, wells are divided into three groups based on mutual interference of wells when pumped. Water levels measured in 43 wells April 2, 1973 are reported.

Changes in water levels between the 1973 measurements and April 1, 1972 measurements are calculated. Some wells showed an increase while other wells showed a decrease in depth to water. Pumpage of water from selected wells from April 1971 to March 1972 and from April 1972 to March 1973 is displayed graphically. Pumpage by group is tabulated yearly from 1965 through 1973 and an average pumpage for that time period also is reported. Surface-water flow in Crow Creek and Lone Tree Creek also is noted. Selected hydrographs are included for each group. Water-level monitoring was, in some cases, recommended to be reduced from monthly to quarterly measurements, based on the comparability of selected monitor wells to water levels of other wells in the field. A water-level contour map for April 2, 1973 is included.

In the Federal well field, the depth to water on April 2, 1973 is reported for eight wells and the net change in water levels between April 1, 1972 and April 2, 1973 is calculated. All wells in the Federal well-field showed a decrease in the depth to water. Pumpage of water from selected wells from April 1971 to March 1972 and from April 1972 to March 1973 is displayed graphically. Pumpage for the field is tabulated yearly from 1965 through 1973 and an average is also reported. Selected hydrographs are included.

KEY WORDS: Ground water, water levels, pumpage, Cheyenne well field, Federal well field, hydrographs, change in water levels, water-level contour map, monitoring, surface water

LOCATION: U.S. Geological Survey 
Ringen, B.H., 1974, Summary of water-level and pumpage data in the Cheyenne and Federal municipal well fields, April 2, 1973 to April 1, 1974: U.S. Geological Survey Open-File Report, 33 p.

Data and analysis in this report are separated into the Cheyenne well field and the Federal well field.

The wells in the Cheyenne well field are divided into three groups based on mutual interference of wells when pumped. Water levels measured in 78 wells April 1, 1974 are reported. Changes in water levels between the 1974 measurements and April 2, 1973 measurements are calculated. Wells showed both increases and decreases in depth to water. Pumpage of water from all wells from April 1973 to April 1974 is displayed graphically. Surface-water flow in Crow Creek, Lone Tree Creek, Spring Creek, Diamond Creek, Clear Creek, Carlot Creek also is noted. Selected hydrographs are included. A water-level contour map for April 1, 1974 is included.

In the Federal well field, the depth to water April 1, 1974 is reported for eight wells and the net change in the water levels between April 2, 1973 and April 1, 1974 is calculated. All wells showed a decrease in the depth to water. Pumpage from each well is displayed graphically. Selected hydrographs are included.

KEY WORDS: Ground water, water levels, pumpage, Cheyenne well field, Federal well field, hydrographs, change in water levels, water-level contour map, monitoring, surface water

LOCATION: U.S. Geological Survey

Ruby, N. K., Sagmeister, R. J., and Green, S. L., 1991, Index of surface-water discharge, water-quality, sediment, and biological records through September 30, 1990, for Wyoming: U.S. Geological Survey Open-File Report 91-497, 46 p.

This report lists the station name, identification number, drainage area, and period of record when systematic surface-water data collection for discharge, water-quality, sediment, and biological information occurred prior to Oct. 1, 1990. Miscellaneous surface-water measurements are not indexed in this report nor are any ground-water records included. Various sites on Middle Crow Creek, South Crow Creek, North Crow Creek, Crow Creek, South Fork Lodgepole Creek, Ninemile Draw, and Lodgepole Creek in the area of the Cheyenne well fields are indexed.

KEY WORDS: Surface water, discharge, water quality, biology

LOCATION: U.S. Geological Survey 
Stanley, K.O., 1971, Tectonic implications of Tertiary sediment dispersal on the Great Plains east of the Laramie Range: 23rd Annual Field Conference Guidebook, Wyoming Geological Association, p. 65-70.

Stanley discusses sediment sources and depositional environments of formations of Tertiary age in eastern Wyoming, western Nebraska, and northeastern Colorado. He concludes that sediment transport directions were primarily east-northeast in the Cheyenne area during the time of deposition. He notes that lower Tertiary deposits are absent close to the Laramie Range.

KEY WORDS: Geologic deposition, Ogallala Formation, Arikaree Formation, Laramie Range, Tertiary, Miocene

LOCATION: University of Wyoming Geology Library

States West Water Resources Corporation, 1990, Crow Creek ground water recharge project, Level II evaluation: Cheyenne, Wyo., report submitted to the City of Cheyenne, $77 \mathrm{p}$.

This report was completed following a study on the feasibility of using treated wastewater from Cheyenne to recharge the aquifer near Carpenter, Wyoming. Several methods were discussed for recharging the aquifer. The most feasible method identified was to use numerous small dams in the Crow Creek valley to impound the water while allowing it to infiltrate into the aquifer.

KEY WORDS: Aquifer recharge, wastewater, artificial recharge, Crow Creek

LOCATION: Cheyenne Water and Sewer Department

The Earth Technology Corporation, 1984, Aquifer simulation of proposed Peacekeeper project water supply: Cheyenne, Wyo., report submitted to the U.S. Department of the Air Force, Ballistic Missile Office, 144 p., 5 pls.

This report was completed for the U.S. Air Force in response to plans to increase the number of missiles located in the Cheyenne area. This plan was projected to cause an increased demand on the Cheyenne water system. The report used computer modeling to simulate drawdowns in the well fields from increased pumping. Various aquifer pumping schemes were analyzed, and one scheme that increased pumping rates in the Bell well field was selected. The report concluded that the current system would supply any increased demand from the Air Force project adequately, but recommended rehabilitating several wells.

KEY WORDS: Water supply, Peacekeeper, Air Force, Cheyenne, wells, well-field pumpage, well rehabilitation

LOCATION: Cheyenne Water and Sewer Department 
The Earth Technology Corporation, 1984, Reconnaissance evaluation of the water-supply development potential of the Paleozoic Aquifer near Cheyenne, Wyoming: Long Beach, Calif., The Earth Technology Corporation, Inc., prepared for the U.S. Department of the Air Force, Ballistic Missile Office, Norton Air Force Base, Calif., 50 p.

This reconnaissance evaluation of the Paleozoic aquifer was completed in anticipation of additional water demand caused by projected deployment of 100 Peacekeeper missiles in the area around Cheyenne. The report evaluates the water-supply potential of the Casper Formation at four areas -- Granite-Harriman, Cheyenne Pass, Horse Creek and Farthing. A summary of previous investigations is presented and an extensive bibliography is included.

For each of the four areas, a geologic map, a cross-section, the thickness of the Casper Formation, cementation, the dip of beds, and a discussion of structure are presented. Limited water-quality and transmissivity data are included under the discussion of regional hydrogeology. The hydrogeologic implications of the geologic features are considered. Recharge potential is discussed.

The Farthing area was rated as having moderate to high water-supply development potential, with the other three areas listed as having low potential.

KEY WORDS: Casper Formation, Casper aquifer, geologic maps, recharge, water-supply potential, GraniteHarriman area, Cheyenne Pass area, Horse Creek area, and Farthing area

LOCATION: U.S. Geological Survey

Theis, C.V., 1941, Preliminary memorandum on ground-water supply of Cheyenne, Wyoming (with two plates)

This memorandum was completed for the Quartermaster Corps of the U.S. Army in response to an increased water-supply demand at Fort Francis E. Warren (now Francis E. Warren Air Force Base), Wyoming, at the beginning of World War II. Three wells, Holman, Elkar, and Bailey No. 1, located 6 miles west of Cheyenne, were being used as public water-supply for Cheyenne in 1940. A general discussion of area geology is included. Potential recharge and discharge relations between aquifers, precipitation, and streams are presented. This author places the Brule Formation at a shallower depth than is listed in many later reports. Specific capacities and transmissibilities from aquifer tests conducted at six wells are reported. An estimated water balance is presented. Three recommendations are presented: (1) the well field, if operated correctly, probably could yield sufficient water for the increased Fort Warren activity, (2) weekly water levels and production records should be kept for each well, and (3) the City should study the ground-water resources in more detail.

KEY WORDS: Water supply, ground water, geology, recharge, water balance, specific capacity, transmissivity,

LOCATION: U.S. Geological Survey. Only one copy of this report was located. 
Western Water Consultants, Inc., 1982, Ground-water development potential for the Paleozoic aquifer along the flanks of the Laramie Range and Hartville Uplift, southeastern Wyoming: Laramie, Wyo., Report prepared for the Wyoming Water Development Commission, 88 p., 6 pls.

This report presents a reconnaissance evaluation of potential sites for ground-water development in the Paleozoic aquifer. The study area lies within the boundaries of $41^{\circ} 00^{\prime}$ and $42^{\circ} 51^{\prime}$ latitude and $104^{\circ} 17^{\prime}$ and $106^{\circ} 42^{\prime}$ longitude. The following data are developed and presented in the report:

- Stratigraphic correlation of rocks of Paleozoic age

- Elevation of the top of the combined Casper and Tensleep Formation

- Potentiometric surfaces associated with the Paleozoic aquifer

- Geologic map showing outcrops of the Paleozoic rocks

- Map showing water sampling sites and total dissolved-solids concentrations of water

- Location of favorable and existing sites for ground-water development

- Location of wells, completed in the Paleozoic aquifer, that have water rights

Within Laramie County, two sites near the Platte and Laramie County line, one near Iron Mountain, one near Farthing, one near Islay, and one near Spottlewood Creek were identified as favorable sites for potential ground-water development in the Paleozoic aquifer.

For each site, the target interval, favorable geologic structure, percent sandstone, known aquifer characteristics, expected potentiometric surface, anticipated water quality, contributing recharge area, favorable hydrologic characteristics, and depth to top of target interval is discussed or estimated. The report includes excellent tables of data, maps, and a list of references.

KEY WORDS: Paleozoic aquifer, ground-water development potential, water quality, aquifer characteristics, geologic structure, data

LOCATION: Western Water Consultants, Inc. Office, Laramie, Wyoming 
Wester-Wetstein and Associates, Inc., 1994, Construction and testing of the Weber No. 1 well, report submitted to the City of Cheyenne, 99 p., geophysical logs.

The City of Cheyenne in 1993 decided to replace the failing Weber well with a new well. The new well is located in the Borie well field, six miles southwest of Cheyenne, in the NE 1/4 of the NE 1/4, Section 24, Township 13 North, Range 68 West. The well was drilled to a depth of 395 feet and was completed in the Ogallala and White River Formations. The static-water level in the well was 34.8 feet.

From drawdown and recovery aquifer tests conducted on the well, it was determined that the aquifer near the well had transmissivities ranging from 5,100 to 6,500 gallons per day per foot of drawdown $(\mathrm{gpd} / \mathrm{ft})$. A transmissivity of 5,800 $\mathrm{gpd} / \mathrm{ft}$, derived from a Jacob analysis of drawdown data was selected as the most accurate value. A storage coefficient of $1.4 \times 10^{-4}$ was also determined from the Jacob method. It was noted that after 7,000 minutes of pumping, interference from a nearby industrial well could be observed in the drawdown data. Safe-yield analysis, based on impacts to nearby wells and drawdown in the pumping well, found that a pumping rate of 350 gallons per minute was sustainable.

Water-quality testing from the replacement well was reported to meet all U.S. Environmental Protection Agency primary and secondary drinking-water standards.

KEY WORDS: Cheyenne, Borie well field, ground water, Weber well, water quality

LOCATION: Cheyenne Water and Sewer Department

Weston Engineering, Inc., 1994, Cheyenne Far (Park) test well report, Unpublished memorandum submitted to the City of Cheyenne, 12 p., geophysical logs.

A test well was drilled into the Lance Formation in the NW 1/4 of the SE 1/4, Section 16, Township 14 North, Range 66 West to evaluate the feasibility of developing water to maintain a city park. The test well was drilled to a depth of 1,130 feet. Formations of Tertiary age were reported to be about 780 feet thick at the test well and were composed of thin layers of sandstones and claystones. The Upper Cretaceous Formations were composed of thin sandstones, siltstones, and shales. Lithologic and geophysical logs for the test well are appended to the memorandum.

Water-quality analysis of water collected from two wells, the test and a private well, completed in the Lance Formation determined that the water met U.S. Environmental Protection Agency standards for drinking water. A report of the water quality from the existing, private well is included in the memorandum. A Theis analysis to determine the impacts on existing wells from pumping the proposed well is presented.

KEY WORDS: Geology, ground water, water quality, Lance Formation, Cheyenne

LOCATION: Cheyenne Water and Sewer Department 
Weston Engineering, Inc., 1996, Cheyenne 10 well rehabilitation report: Cheyenne, Wyo., report submitted to the Cheyenne Board of Public Utilities, 258 p., 2 plates, 15 geophysical logs.

This report was completed following the rehabilitation of 10 municipal wells. The report summarizes the geology of the well fields. The results of aquifer tests performed on the rehabilitated wells were used to calculate transmissivities and storage coefficients. The aquifer tests showed that leaky-aquifer conditions exist in the Borie well field.

Also included are lithological and geophysical logs for test wells. Water-quality data are presented. Information on test wells completed in deposits of Upper Cretaceous age is also included.

KEY WORDS: Geology, Tertiary, well information, Ogallala Formation, White River Formation

LOCATION: Cheyenne Water and Sewer Department

Weston Engineering, Inc., 1995, Geologic cross-section across the Bell well field, report submitted to the Cheyenne Board of Public Utilities, 1 plate.

This geologic cross-section depicts the subsurface geology of the Bell wellfield, from the Ogallala Formation to the Lance Formation. The cross-section depicts gravel channels and laterally discontinuous beds within the formations of Tertiary age. The data for the crosssection were derived from lithologic and geophysical logs of Cheyenne municipal wells.

KEY WORDS: Bell well field, geology, cross-section, Ogallala Formation, White River Formation, Lance Formation

LOCATION: Cheyenne Board of Public Utilities computer system

Wiersma, U.M., 1989, Structural obstruction of recharge to the Paleozoic aquifer in the Denver-Julesburg Basin along the Laramie Range, Wyoming: Laramie, Wyo., M.S. Thesis, Department of Geology, University of Wyoming, 56 p., 5 pls.

The author discusses Paleozoic Formations west and northwest of Cheyenne. The author concludes that thrust faults created during the Laramide orogency prevent recharge of ground water to the Casper Formation into the basin. No conclusions are discussed addressing recharge in Paleozoic Formations south of I-80. The author has drawn the major thrust fault in the study area farther west than previous interpretations.

KEY WORDS: Laramie Range, thrust fault, recharge, Paleozoic, Casper Formation

LOCATION: University of Wyoming Geology Library 
Wyoming Water Planning Program, 1973, Wyoming's Groundwater Supplies: Cheyenne, Wyo., Wyoming State Engineer's Office, 28 p.

This report identifies the Ogallala Formation as the major aquifer of Tertiary age in the Cheyenne area and as an integral part of the municipal-water supply for Cheyenne. An increase in ground water depletion by the year 2020 was projected for the Cheyenne area. Specific capacities are listed for valley alluvium, terrace alluvium, Ogallala and the Arikaree Formations, and the Brule and Chadron Members of the White River Formation.

KEY WORDS: Ground-water development, specific capacity, alluvium, terrace alluvium, Ogallala, Arikaree, Brule, Chadron, White River

LOCATION: U.S. Geological Survey 


\section{SUMMARY}

Annotated bibliographies for 55 hydrology and geology manuscripts pertaining to the Cheyenne municipal wells fields are listed in this report. For each manuscript, a citation is provided, a summary paragraph is presented, key words are listed, and a repository for the manuscript is given. The report lists manuscripts, conference proceedings, and guidebooks published by the U.S. Geological Survey, State of Wyoming, Geological Society of America, Wyoming State Geological Survey, private consultants, and University of Wyoming.

Information on geologic formations, structural geology, aquifer characteristics, water levels, well-field production, water-demand projections, and water quality is included in the manuscripts.

The earliest manuscript identified in this research was published in 1910 by N. H. Darton and others. Since that time, a total of 55 manuscripts have been produced that address various issues in the area of the Cheyenne municipal well fields. Some manuscripts did not receive broad distribution or indexing, and were difficult to locate. For some manuscripts, only one copy is known and it contains original data and analysis and in some cases, original hand-colored geologic maps.

Information presented in this report will assist the managers of water supplies in the Cheyenne area and other users of hydrologic information by making previous work accessible. By having the references and summaries within one report, time and effort to gather previous study results will be minimized. Managers can use this report to determine what existing data are available and to take advantage of previous knowledge for new studies. 